Portland State University

PDXScholar

Systems Science Faculty Publications and

Presentations

Systems Science

2001

\title{
Transforming Technology Management Courses for Web Delivery
}

Wayne Wakeland

Portland State University, wakeland@pdx.edu

Follow this and additional works at: https://pdxscholar.library.pdx.edu/sysc_fac

Part of the Higher Education and Teaching Commons, and the Scholarship of Teaching and Learning Commons

Let us know how access to this document benefits you.

Citation Details

Wakeland, Wayne, "Transforming Technology Management Courses for Web Delivery" (2001). Systems Science Faculty Publications and Presentations. 68.

https://pdxscholar.library.pdx.edu/sysc_fac/68

This Article is brought to you for free and open access. It has been accepted for inclusion in Systems Science Faculty Publications and Presentations by an authorized administrator of PDXScholar. Please contact us if we can make this document more accessible: pdxscholar@pdx.edu. 


\title{
Transforming Technology Management Courses for Web Delivery
}

\author{
Wayne Wakeland \\ Systems Science Ph.D. Program \\ Portland State University \\ Portland, OR 97207-0751 USA
}

\begin{abstract}
This paper explores the ramifications of using web technology in teaching technology management courses, computer-based modeling and simulation courses in particular. The emphasis is on what works, but disappointments are also mentioned. Web technology is being used to supplant lectures with selfpaced materials and lab exercises that enable students to take courses remotely and asynchronously. Web-based exams are also discussed.
\end{abstract}

\section{INTRODUCTION}

Is the web transforming how we are teaching technology management? It is the author's view that the answer to this question is a resounding yes! However, the specifics of that transformation are not yet obvious. Questions abound. Is the web best used as a more flexible and visual delivery vehicle for course materials? Is it possible to effectively assess student learning in a remote, asynchronous environment? How do we ensure the quality of instruction in web courses?

This paper is a reflection on the author's efforts for the past three years to use web technology to improve a sequence of computer modeling $\&$ simulation courses. The content of the paper may be of interest to other educators who are using or considering the use of web technology in their courses. It is also intended to serve a springboard for scholarly research to address some of the various questions being raised about web-based instruction.

The author has used web technology to replace lectures with self-paced reading materials and labs conducted in computer-equipped classrooms. Students work at their own pace on "labs" that are designed to reinforce key concepts in the readings and exercises. Both the instructor and a lab assistant are available to the students during the lab period. Students are free to do the labs at another location and/or at another time if they so choose. Labs are not graded.

Learning is assessed via projects, examinations, and exercises that are written up and submitted by the students. Self-tests are also available to the students.

Although students might potentially be able to take the courses at a distance, only a few have done so thus far. Most students take advantage of the lab sessions, especially those for whom the material is very challenging. A few students, usually those who are able to master the concepts with minimal instructor assistance, will opt out of the labs or do them on their own time.

The motivation behind web-enabling the courses was not so much to make the courses available at a distance as it was to improve their quality by making them more learner-directed and to improve their efficiency, from both the student's perspective and the instructor's perspective.

\section{THE SUBJECT COURSES}

The courses from which this paper is drawn are computer simulation courses designed to teach students how to use a computer simulation language (the tool) and how to conduct a simulation-based study (the process). One course, entitled "System Dynamics," is focused on continuous system simulation using the STELLA software. The other two courses teach discrete system simulation (DSS), using either Arena or Extend. One DSS course is quite general and emphasizes the interpretation of simulation results using statistics. The other DSS course focuses on process modeling and simulation. All three courses meet once a week in the evening to make them accessible to local professionals as well as full-time graduate students.

For many years, the courses were conducted very traditionally—students read the book and the instructor lectured from handwritten notes, using the chalkboard as appropriate. It was felt that there was value in requiring students to take their own notes. Sometimes, the instructor would hand out typewritten notes to complement or update the texts. Examinations were generally open notes as well as open book, based on the belief that this provided an incentive for students to take good notes. 


\section{EVOLUTION OF THE COURSES}

By late 1997, with the web becoming increasingly ubiquitous, the decision was made to put the notes into html and make them available to students on the web. Non-graded "test your knowledge" quizzes were also developed and provided to students. The latter were discussed during class periods. A detailed roadmap for the entire course was provided via an Excel spreadsheet. Hyperlinks in this spreadsheet took students to the various pages of notes, assignment sheets, and quizzes. The author believed this to be a major improvement over the previous approach.

At this same time, classrooms were being equipped with video projectors and web connections. So, it seemed natural to use the web notes as the lecture notes to be covered during the class time. While this may have been no less effective than the previous approach, it became clear to the instructor that lectures done in this fashion were not adding very much value to the course. A new pedagogical approach was needed.

\section{ACTIVE LEARNING}

Colleagues around campus were engaged in discussions about active learning, student-directed learning, inquiry-based learning, etc. A cursory literature review via the web indicated that prestigious universities such as Harvard and MIT were exploring these new approaches to learning.

The idea seemed simple enough: create materials that require the student to do more than simply read and listen. Have them work in teams to solve problems, do research, create presentations, etc. Another aspect would be to have students check their comprehension regularly as they learn new concepts.

Nelson Baker [1] reports that web materials help students learn subjects more quickly and that some students also learn the subject better, especially lower quartile students. Initial increases in motivation, however, tend to fade over time. The increased visual impact available on the web is an important factor. This implies that simply putting text onto the web would tend to not be of much value. Baker concludes by indicating the characteristics of effective web pages for teaching:

- Well organized

- Easy to navigate

- Content globally integrated

- Collaboration mechanisms available to maintain community

- Samples of previous student work \& discussions available

Active Learning views education not as a passive transmission process but rather as an active process with ample opportunities for clarifying, questioning, applying, and consolidating [5]. Tools for active learning include group discussion, problem solving, case studies, role-playing, journal writing, and structured learning groups. Having students work in pairs is especially recommended.

Silberman [7] discusses active learning and provides a wide variety of activities to make learning unforgettable.

Campbell [3] provides a manual via the web (of course) on cohesive web design, the key to which is interactivity. She refers to Schank and Cleary [6] whose work in cognitive science indicates that humans learn better through experimentation with the real world rather than memorizing lists of rules. Campbell also presents the notion of anchored discussion developed by the Cognition and Technology group at Vanderbilt, where:

- Students explore and resolve complex, realistic problems

- Video materials serve as anchors or macro contexts

Other important concepts from cognitive theory include experiential learning, situated learning, lateral thinking, and social development theory (that says social interaction is the key to cognition). Shank \& Cleary have articulated what they call teaching architectures:

- Simulation-based Learning by Doing

- Incidental Learning

- Learning by Reflection

- Case-based Learning

- Learning by Exploring

Bruner provides a related set of six learning frameworks [2]:

- Multiple Representations of Reality (microworlds) 
- Authentic Tasks

- Real-World, Case-based Contexts

- Fostering Reflective Practice

- Knowledge Construction

- Collaborative Learning

Collins [4] discusses the role of computer conferencing as it relates to interaction and learning, both synchronous and asynchronous. The roles of the on-line instructor and student are contrasted to traditional roles, for example:

- The instructor as consultant, guide, and resource provider rather than as oracle and lecturer

- The teacher as a designer of student learning experiences rather than just a provider of content

- Teachers providing only the initial structure for student work, thereby encouraging selfdirection

Keeping in mind the literature reviewed above, the author continued the process of modifying courses. In general, the changes needed were relatively straightforward. The subject matter lent itself rather naturally to active learning: the goal was for students to learn how to build models, and to use these models to generate insights, inform decisions, etc.

For example, it made (makes) perfect sense to ask students to build several realworld inspired models of increasing complexity, and with decreasing amounts of assistance; and to then conclude the student's learning process by asking them to address a real world problem. Reading books and webnotes would be a means to an end rather than an end in itself.

\section{CONVERSION TO COMMERCIAL WEB COURSE DELIVERY SOFTWARE}

At about this time, Portland State University began to adopt a software program for web course delivery called WecCT from WebCT Inc., Six Kimball Lane, Suite 310, Lynnfield, Massachusetts 01940. It offers a variety of features for conducting courses via the web, including delivery of content, bulletin board discussions, email, chat sessions, electronic quizzes, submission and tracking of assignments, support for teams to make presentations, etc.

Beginning in early 1998, courses were converted to this new WebCT environment. The notes converted easily. The quizzes were much more work. After some early unsuccessful experimentation with short essay questions, the decision was made to convert all questions to a multiple choice format, including immediate feedback to students as to why certain answers were not correct. The calendar feature was used initially to implement the course schedule. This proved not to be as useful as hoped for and was subsequently abandoned in favor of using WebCT's "course content" page as the course roadmap. This is not as flexible as the Excel spreadsheet with hyperlinks used previously, but it is workable.

Also in the background was the thought that the courses should not be locked into a tight time schedule. Students should be able to work at their own pace to the degree possible. This is not consistent with having exact due dates for everything--a dilemma that has not yet been fully resolved.

The instructor began to indicate to students at this time that the courses were no longer lecturebased--that instead they were (and continue to be) web/lab courses.

Initially, during the lab time, instead of lecturing, the instructor built simulation models in order to demonstrate "good practice" for the students. The models were chosen to illustrate various important principles. This worked better than reviewing lecture notes, but it was still too passive; the students were participating to some degree, but it was not as "hands on" as desired.

The answer, beginning in 1999, was to create a specific "lab" for each class period. Koei Kudo, a PSU graduate student, provided considerable assistance with this process. Early in the course, the lab instructions provided are very detailed, with many hints to assist the student to complete the lab. As the course proceeds, the lab instructions become sketchier.

To address the desire to begin de-coupling the course from the strict passage of time, the materials were modularized into topics with the help of a colleague, Dr. Jody House at the Oregon Graduate Institute. Although the topics continue to be grouped into what would nominally take a week to cover, this seems to be a step in the right direction. 


\section{EXAMINATIONS ON THE WEB}

In one of the courses, the Midterm was implemented using multiple-choice questions rather than the previously used short essay format. Two students took this exams at long distance while travelingone from a "CyberCafe" in South America! Although the initial exam proved to be quite problematic due to the instructor's relative inexperience with designing multiple-choice exams, the potential for using such exams was very clear. The exam in question has been "repaired" and will be used again in the future.

A concern with exams is whether or not they should continue to be open notes, since the notes are readily available on the web and serve as the backbone of the course. Can an exam really measure understanding when the students are able to simply look up the answers in the notes using web searching? One answer might be not to provide enough time to do such searching. However, this might prove unfair to students for whom English is not their native language, who often need relatively more time for exams.

This is a difficult issue to resolve because there may not be a practical way to prevent students from searching web pages during an exam that is itself delivered via the web. The course delivery software could possibly resolve this by making the content pages temporarily unavailable during exams, but that could be defeated with multiple browser sessions. Furthermore, most students print out the notes, and, while these notes could be disallowed during the exam, it would require the exam to be proctored for remote students. Perhaps it would make more sense to simply allow students to use whatever materials they choose and make sure the answers to the questions cannot be directly obtained from the notes.

\section{STUDENT SURVEY RESULTS}

Surveys were taken for the past two years regarding the web aspects of the System Dynamics course. Student feedback has been mixed regarding some aspects of this course. Table I shows the results of surveying students in 1999 and 2000 about utility of various aspects of the course. The weighted mean was computed by giving strongly twice as much weight. Variance or dispersion was not computed due to the weighting and the fact that it is easily seen in the table.

TABLE I

STUDENT SURVEY DATA

\begin{tabular}{|c|c|c|c|c|c|c|c|}
\hline Weight & & -2 & -1 & 0 & 1 & 2 & \\
\hline & & $\begin{array}{l}\text { Strongly } \\
\text { disagree }\end{array}$ & Disagree & Neither & Agree & $\begin{array}{l}\text { Strongly } \\
\text { Agree }\end{array}$ & $\begin{array}{l}\text { Weighted } \\
\text { Mean }\end{array}$ \\
\hline $\begin{array}{l}\text { 1. Lecture Time was used } \\
\text { effectively }\end{array}$ & 1999 & & 3 & 12 & 4 & & .05 \\
\hline $\begin{array}{l}\text { 2. Lab Time was used } \\
\text { effectively }\end{array}$ & 1999 & & 6 & 2 & 9 & 2 & .37 \\
\hline $\begin{array}{l}\text { 3. Using Contact Time for } \\
\text { Lab vs. Lecture was } \\
\text { effective for me }\end{array}$ & 2000 & 2 & 4 & 5 & 4 & 5 & .30 \\
\hline \multirow[t]{2}{*}{ 4. The Labs were useful } & 1999 & 1 & & 5 & 9 & 3 & ,72 \\
\hline & 2000 & & 4 & 1 & 14 & 1 & .60 \\
\hline \multirow[t]{2}{*}{ 5. Labs took too much time } & 1999 & 2 & 7 & 5 & 4 & 1 & -.26 \\
\hline & 2000 & 1 & 8 & 7 & 4 & & -.30 \\
\hline \multirow{2}{*}{$\begin{array}{l}\text { 6. Self Test Quizzes were } \\
\text { useful }\end{array}$} & 1999 & & & & 7 & 12 & 1.63 \\
\hline & 2000 & & & 2 & 7 & 11 & 1.45 \\
\hline \multirow[t]{2}{*}{ 7. Web Notes were useful } & 1999 & & 1 & 1 & 7 & 10 & 1.37 \\
\hline & 2000 & & 2 & 1 & 15 & 2 & .85 \\
\hline $\begin{array}{l}\text { 8. Multiple Choice } \\
\text { Midterm was OK }\end{array}$ & 2000 & 1 & 2 & 2 & 9 & 6 & .85 \\
\hline $\begin{array}{l}\text { 9. I believe the material } \\
\text { could be learned as well or } \\
\text { better via well-designed } \\
\text { web course }\end{array}$ & 1999 & 2 & 7 & 1 & 6 & 3 & .05 \\
\hline 10. Taking course remotely & 2000 & & 3 & & 11 & 6 & 1.00 \\
\hline
\end{tabular}




\begin{tabular}{|l|l|l|l|l|l|l|l|}
\hline $\begin{array}{l}\text { and asynchronously } \\
\text { worked for me }\end{array}$ & & & & & & & \\
\hline $\begin{array}{l}\text { 11. WebCT access was not } \\
\text { a problem overall }\end{array}$ & 2000 & 1 & & 2 & $\mathbf{1 0}$ & $\mathbf{7}$ & 1.10 \\
\hline $\begin{array}{l}\text { 12. Relying on the WebCT } \\
\text { Bulletin Board for } \\
\text { important course info. } \\
\text { worked well for me. }\end{array}$ & 2000 & & 2 & 1 & 1 & 2 & .50 \\
\hline
\end{tabular}

As can be seen in Table I, in 1999, students were very neutral about the usefulness of the lectures (row 1), and were only slightly more enthusiastic about how lab time was used (row 2), due no doubt to the fact that the lab time was used for lectures and instructor demonstrations of the software and how to build models. The students never-the-less felt that the labs were useful (row 4, 1999).

In 2000, different questions were asked, but the results remained mixed. Some students appear to lament the loss of the lectures (row 3), although most (3/4) of them still find the labs useful (row 4, 2000) and not overly time-consuming (row 5, 2000). Overall, these results suggest to the author that there is still much room for improvement in how instructor contact time is used.

Self-test quizzes were equally useful when converted to WebCT (row 6). Curiously, the mode of the response regarding the usefulness of the web notes dropped from "strongly agree" to "agree" (row 7). Most students felt that the multiple-choice midterm worked fine (row 8).

In 1999, students were asked their opinion about moving the course more fully to the web. The results were bimodal, with half the class saying "yes" and half saying "no" (row 9). In 2000, 85\% of the students indicated a good experience with using the web (rows 10 and 11). Students who relied heavily on the web-based bulletin board to learn about important course information indicated mixed results (row 12).

\section{PRELIMINARY CONCLUSIONS}

The author believes that the courses are getting better. This is mostly a result of the time invested to provide web notes, develop self-test quizzes, create labs, etc. These improvements could have been done without web technology. The web simply provided the impetus and made the materials easier to deliver.

It is also clear that there is much room for improvement regarding every aspect of the courses. The materials are still quite static and "beg" to be made more dynamic, especially in light of the capabilities available on the web. Also, the self-test capability needs to be much more complete. The glossary capability needs to be better exploited, and student interaction during the labs needs to be improved. Some amount of "lecture time" may need to be re-incorporated in order to maximize student learning and satisfaction.

It is evident that the experience for remote students is inferior to the experience provided to the students who are able to attend the lab sessions in person.

\section{FUTURE POSSIBILITIES}

The author would like to try using technology such as Microsoft NetMeeting to "publish" the lab sessions so that students taking the course remotely could participate in them synchronously. This would allow the remote students to see what the local students see and to hear what the instructor is saying, especially when the instructor demonstrates something on the computer. A chat-type dialog window could be used to allow remote students to ask questions that would be answered verbally by the instructor.

Chat room sessions at pre-scheduled times, where the instructor types his or her responses might also be feasible, but would be less efficient for the instructor than being able to respond vocally using a microphone.

Streaming video technology may help to improve the learning experience for remote students.

\section{INDICATIONS FOR FUTURE RESEARCH}


Much more data is needed regarding both the quality and efficiency of web-based learning--for different subjects, for learners of varying ability from the lower quartile to upper quartile, and, ideally, for different aspects of web instruction.

WebCT already provides considerable tracking capability, and, as course delivery software such as WebCT matures, it should be possible to obtain data that would allow the analyst to correlate the amount of time students spend on various modules with their performance on both self-tests and graded exams.

Comparing the quality of learning will require that the same exam be given to students taking similar courses that are traditional and web-based. This will no doubt require the cooperation of instructors at multiple institutions.

Comparing efficiency data between web and traditional classes will be even more difficult, since there is no mechanism in traditional courses for keeping track of how long students spend reading, doing assignments, etc. This will require the cooperation of the students as they take the course.

Despite the difficulty of doing this research, it must nevertheless be done in order to understand when to use and when not to use various types of web-based instruction, and for which subjects and for which students.

\section{REFERENCES}

[1] Baker, Nelson, Georgia Tech., “Teaching and Learning Using the Web,” presentation given at Clemson Univ., 2/19/99.

[2] Bruner, J., Active Minds, Possible Worlds, Harvard University Press, Cambridge, MA, 1986.

[3] Campbell, Katy, “The Web: Design for Active Learning,” http://www.atl.ualberta.ca/articles/idesign/active1.cfm, 8/26/99.

[4] Collins, Mauri, “Facilitating Interaction in Computer Mediated Online Courses,” FSU/AECT Distance Education Conference, Tallahassee FL, June, 1996. http://star.uss.nau.edu/ mauri/moderate/flcc.html

[5] http://www1.umn.edu/ohr/teachlearn/MinnCon/active.html, 7/28/99.

[6] Schank, R.C., \& Cleary, C., Engines for Education, Lawrence Eelbaum Associates, Hillsdale, NJ, 1995.

[7] Silberman, Mel, Active Learning: 101 Strategies to Teach Any Subject, Temple University, 1996. 